\title{
Intraseasonal variability of the North Brazil Undercurrent forced by remote winds
}

\author{
D. Veleda, ${ }^{1,2}$ M. Araujo, ${ }^{1,2}$ R. Zantopp, ${ }^{3}$ and R. Montagne ${ }^{4}$ \\ Received 27 July 2012; revised 9 October 2012; accepted 10 October 2012; published 21 November 2012.
}

[1] Intraseasonal signals with periods of 2 to 3 weeks in near-surface alongshore current measurements are detected from four moorings (K1-K4) deployed from 2000 to 2004 at the $11^{\circ} \mathrm{S}$ section close to the Brazilian coast as part of the German CLIVAR Tropical Atlantic Variability Project. This section crosses the path of the North Brazil Undercurrent, the most powerful western boundary current in the South Atlantic Ocean. We investigate the origin of this intraseasonal variability of the North Brazil Undercurrent by relating the oceanic oscillation of the alongshore currents to its atmospheric counterpart, the meridional wind stress. On average, the results indicate a well-defined lagged (10 days) correlation $(\sim 0.6)$ structure between meridional wind stress and alongshore currents. The oceanic region with the highest cross-correlations is identified as a relatively narrow band along the Brazilian coast, from $22^{\circ}-36^{\circ} \mathrm{S}$ and $40^{\circ}-50^{\circ} \mathrm{W}$, bounded in the north by an eastward change in coastline orientation. The cross-wavelet transform establishes the common power between the time series of meridional wind stress and alongshore currents, predominantly during austral winter and spring. These signals propagate equatorward with an alongshore speed of $285 \pm 63 \mathrm{~km}^{-1}{ }^{-1}$, consistent with Coastal Trapped Wave theory.

Citation: Veleda, D., M. Araujo, R. Zantopp, and R. Montagne (2012), Intraseasonal variability of the North Brazil Undercurrent forced by remote winds, J. Geophys. Res., 117, C11024, doi:10.1029/2012JC008392.

\section{Introduction}

[2] Over the past few decades, the western boundary currents of the tropical South Atlantic and their associated scales of variability have been investigated by numerous researchers [Molinari, 1983; Stramma, 1991; Schott and Böning, 1991; Mayer and Weisberg, 1993; Schott et al., 1993; Rhein et al., 1995; Stramma et al., 1995; Dengler et al., 2004; Schott et al., 2005]. While the Deep Western Boundary Current (DWBC) transports cold North Atlantic Deep Water far into the southern hemisphere, the North Brazil Undercurrent (NBUC) and North Brazil Current (NBC) serve as a northward warm-water conduit as part of the thermohaline overturning cell [Gordon, 1986; Schmitz, 1995]. The South Atlantic Central Water (SACW), located at depths between 100 and $500 \mathrm{~m}$, is transported westward within the southern band of the South Equatorial Current (sSEC) until it reaches the Brazilian shelf. After the sSEC bifurcates, its southward

\footnotetext{
${ }^{1}$ Laboratório de Oceanografia Física Estuarina e Costeira, Departamento de Oceanografia, Universidade Federal de Pernambuco, Recife, Brazil.

${ }^{2}$ CEERMA-Centro de Estudos e Ensaios em Risco e Modelagem Ambiental, Universidade Federal de Pernambuco.

${ }^{3}$ GEOMAR Helmholtz Centre for Ocean Research Kiel, Kiel, Germany.

${ }^{4}$ Departamento de Física, Universidade Federal Rural de Pernambuco, Recife, Brazil

Corresponding author: D. Veleda, Laboratório de Oceanografia Física Estuarina e Costeira, Departamento de Oceanografia, Universidade Federal de Pernambuco, Av. Arquitetura s/n, 50740-550, Cidade Universitária, Recife, PE, Brazil. (doris.veleda@ufpe.br)

(C)2012. American Geophysical Union. All Rights Reserved. 0148-0227/12/2012JC008392
}

limb becomes the Brazil Current (BC) and merges into the South Atlantic subtropical gyre system. The northward limb feeds into the NBUC [Stramma and Schott, 1999; Stramma et al., 2005] and - as a western boundary current - carries warm waters of South Atlantic origin across the equator and into the northern hemisphere. It also supplies the eastward flow of the South Equatorial Countercurrent (SECC) which partially recirculates into the central band of the SEC (cSEC). In addition, in the 50-300 $\mathrm{m}$ depth range, the NBUC seems to play an important role in the Atlantic Equatorial Gyre [Schott et al., 2005] and in the coupled ocean-atmosphere system. This strong western boundary current has a nearshore core position approximately $50 \mathrm{~km}$ from the Brazilian coast, reaching down to about $900 \mathrm{~m}$ in depth, with a maximum speed of about $65 \mathrm{~cm} \mathrm{~s}^{-1}$ at 180 to $250 \mathrm{~m}$ on average. At $11^{\circ} \mathrm{S}$, the mean flow structure of the NBUC is already well developed, indicating that the bifurcation of the sSEC is located well south of this section with a maximum northward NBUC flow in July and a minimum in the October-November period [Schott et al., 2005]. The sSEC bifurcation has a southernmost position in July and a northernmost position in November [Rodrigues et al., 2007; Silva et al., 2009].

[3] While the dominant fluctuation in the NBUC core, approx. $50 \mathrm{~km}$ from the coast, has a period of about two months [Schott et al., 2005], biweekly signals are the dominant modes along the western (onshore) flank of the NBUC, about $10 \mathrm{~km}$ from the coast [von Schuckmann, 2006].

[4] The cause of these intraseasonal fluctuations in the upper-ocean circulation may be found in several dynamic processes, such as local wind-forcing, remote wind-forcing via waveguide dynamics, mean flow instability, and resonance 


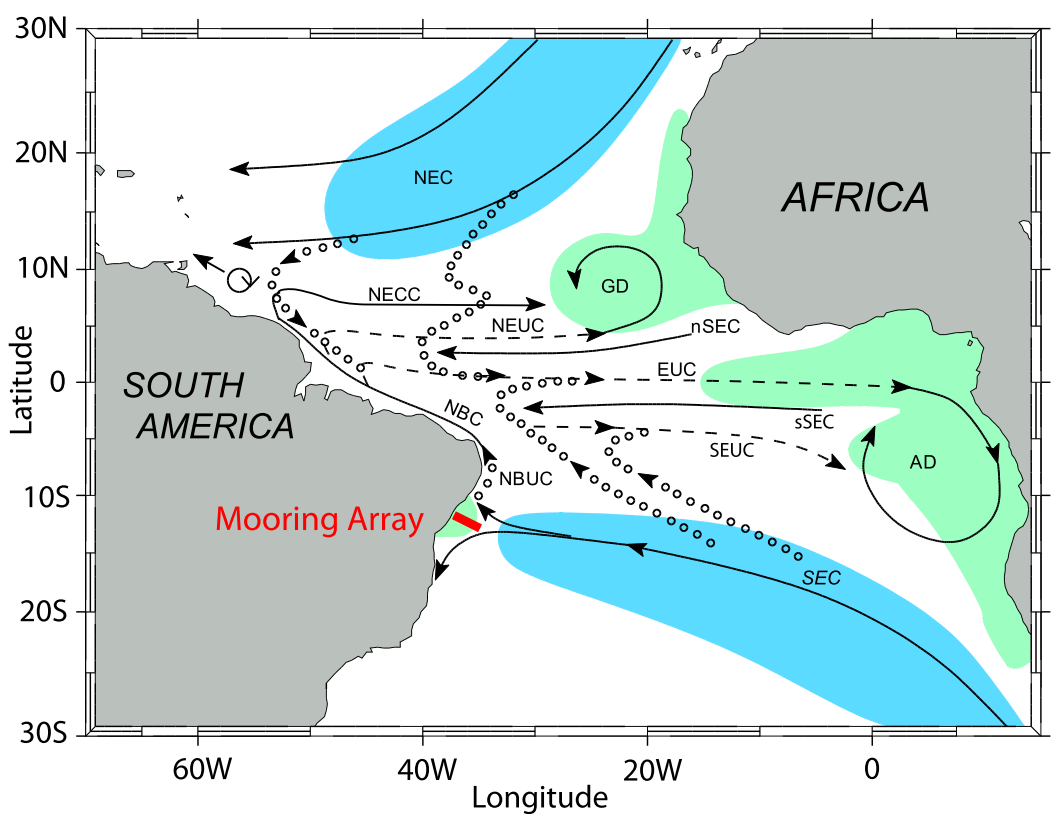

Figure 1. Schematic representation of the Atlantic Subtropical Cell (STC) circulation, including subduction (blue) and upwelling (green) zones. Current branches involved in the STC flows are NEC, SEC, sSEC, NECC and EUC; NEUC, SEUC = North and South Equatorial Undercurrent; NBC, NBUC = North Brazil Current and Undercurrent; GD, $\mathrm{AD}=$ Guinea and Angola domes. Interior equatorward thermocline pathways dotted. Adapted from Schott et al. [2004]. The mooring array at $11^{\circ} \mathrm{S}$ is shown by the red line.

due to the coastline geometry [von Schuckmann, 2006]. Furthermore, if these fluctuations are in reasonable proximity of the coast, the motion of oceanic waters over the continental shelf and slope may also be influenced by the earth's rotation, density stratification, the offshore current regime, sloping bottom topography and the presence of the coastline [Allen, 1980], causing coastal-trapped waves (hereafter CTWs). The existence of CTWs depends entirely on the presence of a shallow shelf between the coast and the deep ocean. CTWs propagate along the continental slopes and shelves of the world's coastlines, with the coast to the right in the Northern Hemisphere and to the left in the Southern Hemisphere. They have periods of days to 2-3 weeks and wavelengths on the order of $2000 \mathrm{~km}$, determined by the atmospheric weather patterns. The impact of CTWs on shelf currents and sea level varies with seasonal changes in stratification over the coast. For arbitrary topography and stratification, there is a free-wave mode (similar to the barotropic Kelvin wave) plus an infinite set of higher mode, more slowly propagating waves [Brink, 1991]. These perturbations induce variations in sea level and alongshore currents over the continental shelf for typical periods ranging from the inertial period to about 20 days. Winds and tides in coastal regions at sub-inertial frequencies force these waves with periods ranging from days to weeks. Since the continental shelf is a transition zone between the coastal waters and the open ocean, the CTWs transport materials (e.g., nutrients and pollutants) from regions near the coastline to and from the open ocean, and along the continental margins. Thus, CTWs modulate the upwelling system and primary productivity in the coastal regions.

[5] This paper investigates the relationship between observed intraseasonal fluctuations in alongshore current measurements near the Brazilian shelf and the large-scale wind stress field over the South Atlantic through the use of cross-correlations and continuous wavelet transforms.

\section{Data}

\subsection{Moored Array Observations at $11^{\circ} \mathrm{S}$}

[6] The ocean data set used here was obtained between March 2000 and August 2004 as part of the German CLIVAR Tropical Atlantic Variability Project [Schott et al., 2005]. The data were collected in an array of five moorings (K1-K5) stretching $225 \mathrm{~km}$ across the NBUC $\left(10^{\circ} \mathrm{S}-11.5^{\circ} \mathrm{S}\right)$ (Figure 1). Data sources, positions and sampling periods are presented in Table 1. Since the offshore mooring K5 was deployed for only two years, and observations were confined to depths below $1500 \mathrm{~m}$. this mooring was not used in the present analysis. Additional details of this data set are given by Schott et al. [2005].

Table 1. Location and Sampling Periods for Moorings and Wind Stress Data

\begin{tabular}{lcc}
\hline \multicolumn{1}{c}{ Data Source } & Latitude/Longitude & Sampling Period \\
\hline Moorings, German CLIVAR Project & $10^{\circ} 16.0^{\prime} \mathrm{S}$ & $02 / 2002-01 / 2003$ \\
Station K1 & $35^{\circ} 51.7^{\prime} \mathrm{W}$ & $06 / 2003-08 / 2004$ \\
& $10^{\circ} 22.8^{\prime} \mathrm{S}$ & $02 / 2002-05 / 2004$ \\
Station K2 & $35^{\circ} 40.8^{\prime} \mathrm{W}$ & \\
& $10^{\circ} 36.7^{\prime} \mathrm{S}$ & $05 / 2003-08 / 2004$ \\
Station K3 & $35^{\circ} 23.4^{\prime} \mathrm{W}$ & \\
& $10^{\circ} 56.5^{\prime} \mathrm{S}$ & $01 / 2002-08 / 2004$ \\
Station K4 & $34^{\circ} 59.5^{\prime} \mathrm{W}$ & \\
& $40^{\circ} \mathrm{S}-0^{\circ} \mathrm{N}$ & $01 / 2002-12 / 2004$ \\
Wind stress data, NOAA/NCDC & $60^{\circ} \mathrm{W}-20^{\circ} \mathrm{E}$ & \\
& &
\end{tabular}



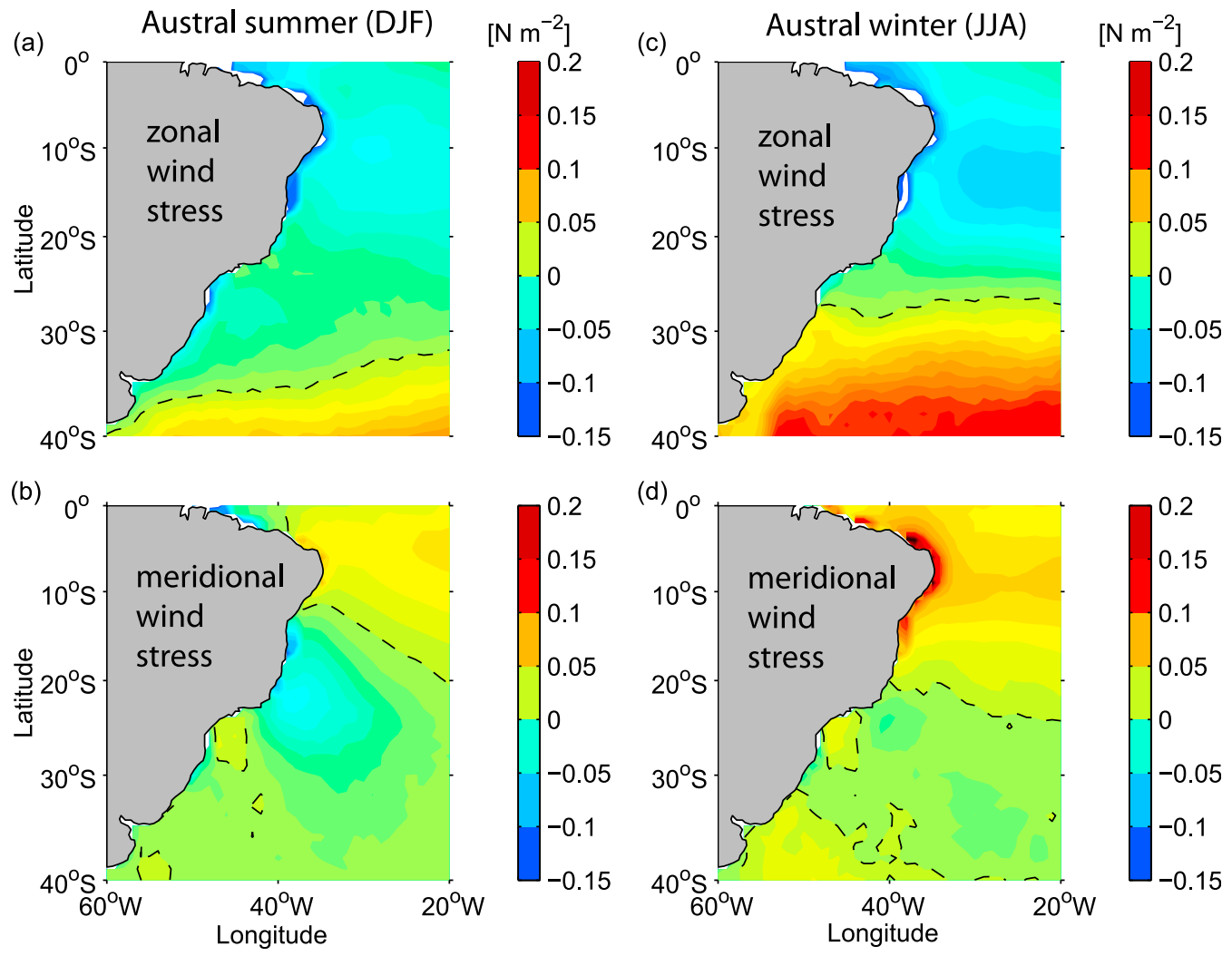

Figure 2. (a, c) Mean zonal and $(b, d)$ mean meridional components of wind stress for austral summer (DJF) and winter (JJA). The zero contours are represented by dashed lines.

\subsection{Wind Stress Data}

[7] The wind stress data set used in this study was obtained from NOAA/NCDC (National Oceanic and Atmospheric Administration/National Climatic Data Center) and is available at www.ncdc.noaa.gov/oa/rsad/seawinds.html. The domain used here covers the area $40^{\circ} \mathrm{S}$ to $0^{\circ} \mathrm{N}$ and $60^{\circ} \mathrm{W}$ to $20^{\circ} \mathrm{W}$ (Figure 2). In this database, surface wind stresses $\left(\mathrm{N} \mathrm{m}^{-2}\right)$ are estimated from blended sea surface wind speeds at $10 \mathrm{~m}$ above sea level, generated from six satellites, on a global $0.25^{\circ}$ regular grid and for several time resolutions [Zhang et al., 2006]. Wind speeds are converted to $(\mathrm{u}, \mathrm{v})$ components using the NCEP Reanalysis 2 (NRA-2). In this work, the wind stress data has a temporal resolution of $12 \mathrm{~h}$.

[8] The mean zonal and meridional components of the wind stress are shown in Figures $2 \mathrm{a}-2 \mathrm{~d}$ for austral summer (DJF) and winter (JJA). These charts capture the main spatial structure of the observed means, in agreement with the published literature [Trenberth et al., 1990; Harrison, 1989; Castelão and Barth, 2006]. During austral summer, the zonal wind is negative (easterlies) over nearly the entire domain, while positive (northward) meridional wind stress is restricted to equatorial latitudes in the western part of the South Atlantic Ocean and negative (southward) for almost the entire western South Atlantic (Figures 2a and 2b). The zonal components of the wind stress are strongest in June, July and August. Northward meridional wind stress is observed in the South Atlantic during JJA, expanding equatorward and reaching $20^{\circ} \mathrm{S}$ in the western basin (Figures $2 \mathrm{c}$ and 2d). Negative (southward) meridional wind stress is found between $20^{\circ}$ and $30^{\circ} \mathrm{S}$, and positive (northward) to the south of it.

\section{Results}

\subsection{Current Structure at $11^{\circ} \mathrm{S}$}

[9] The current meter time series were smoothed using a 40-h lowpass filter to eliminate tidal and inertial effects. Current vectors were divided into alongshore and cross-shore components by rotating clockwise by $36^{\circ}$, i.e., parallel to the coastline. Figure 3 shows the mean section of alongshore velocities at $11^{\circ} \mathrm{S}$ for the entire deployment length (2000 2004); instrument locations for moorings $\mathrm{K} 1-\mathrm{K} 4$ are marked by black dots. The strongest contribution to the NBUC transports occurs near $250 \mathrm{~m}$ depth at moorings K1 and K2 [Schott et al., 2002; Stramma et al., 2003; Schott et al., 2005], indicated by the strong subsurface core in the upper left corner of Figure 3. Below the NBUC, we find the colder water masses of the DWBC, with the core centered at 1500 $3500 \mathrm{~m}$ depth along mooring K3 (dark blue colors). Mooring $\mathrm{K} 4$ is located outside the equatorward boundary current, with a weak mean southward flow between 500 and $3500 \mathrm{~m}$ depth.

[10] Fluctuations about these means are shown as anomalies of the $100 \mathrm{~m}$ current vectors (i.e., demeaned), as at this level the measurements are available for all moorings $\mathrm{K} 1-\mathrm{K} 4$ (Figure 4). The dominant intraseasonal signals have periodicities of 2-3 weeks and 2-3 months (see also Figure 5). The highest amplitudes at periods of 2-3 weeks are found in the coastal boundary region at moorings $\mathrm{K} 1$ and $\mathrm{K} 2$, gradually decreasing away from the NBUC core. Figure 5 shows 


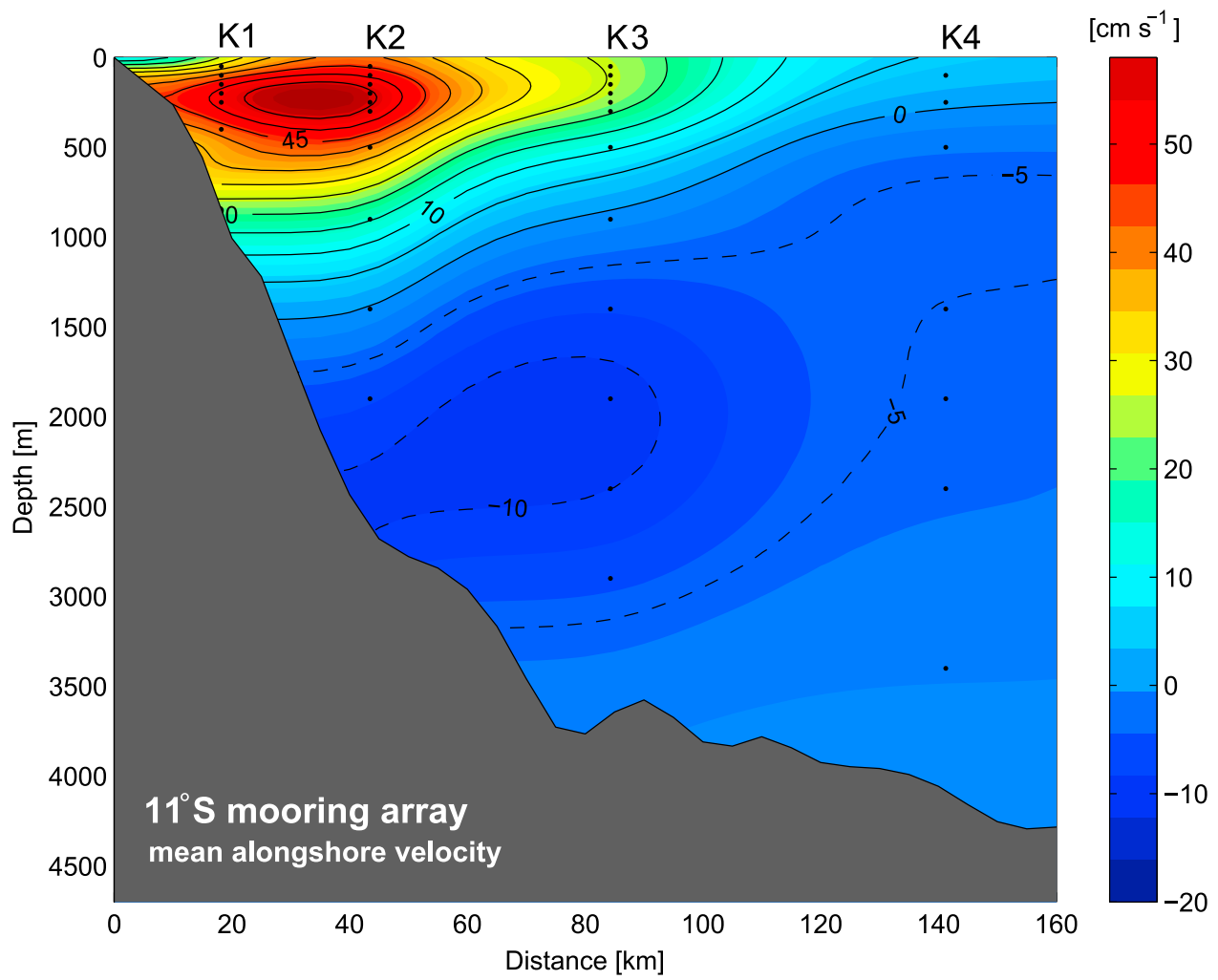

Figure 3. Mean of alongshore velocity at $11^{\circ} \mathrm{S}$, derived from moorings K1-K4. Instrument locations are marked by black dots. Note the equatorward NBUC above $1000 \mathrm{~m}$ and the southward flowing DWBC between 1500 and $3500 \mathrm{~m}$ (adapted from von Schuckmann [2006]).

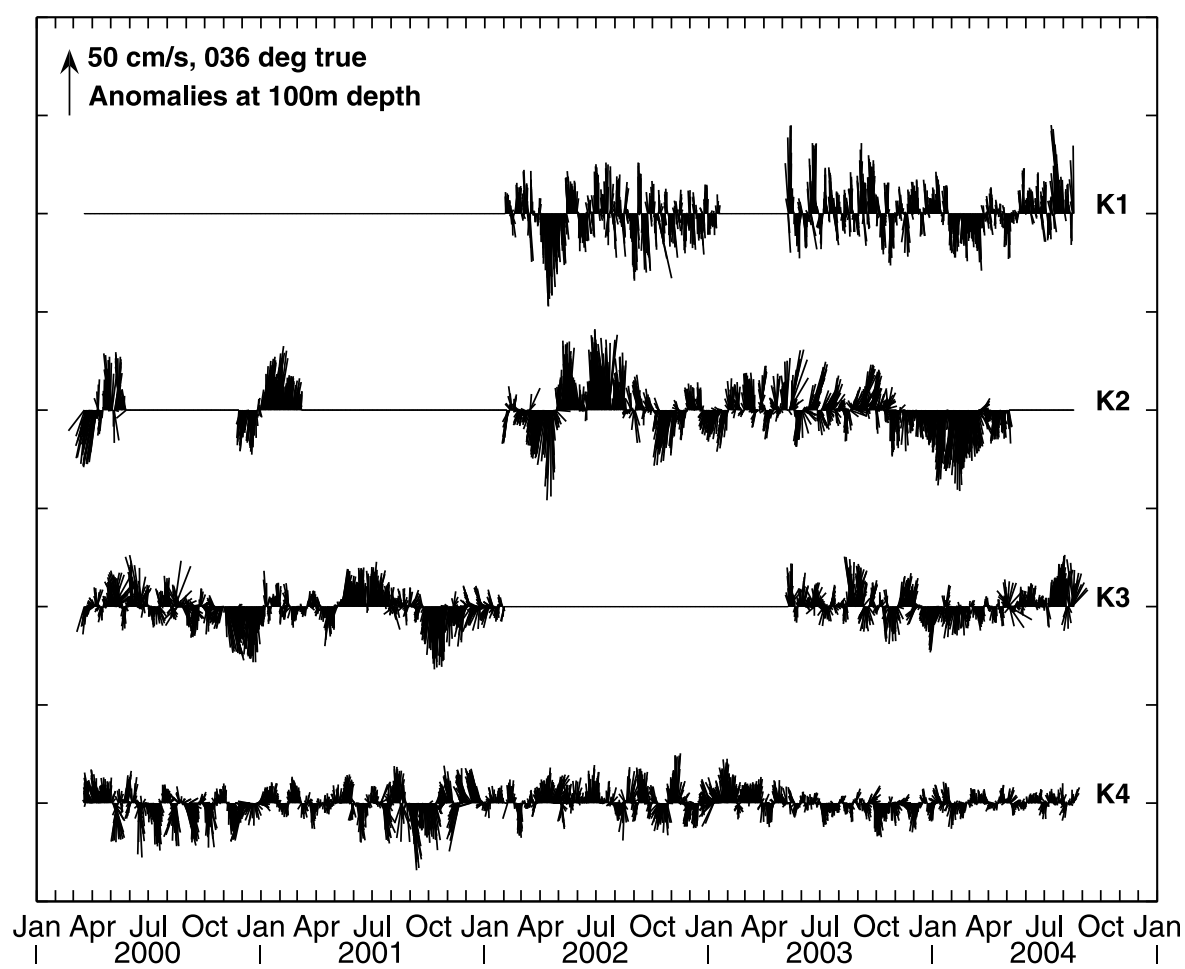

Figure 4. Vector time series of 40-h low-pass filtered alongshore current anomalies at moorings K1-K4 at $100 \mathrm{~m}$ depth, from March 2000 to August 2004. 
K1
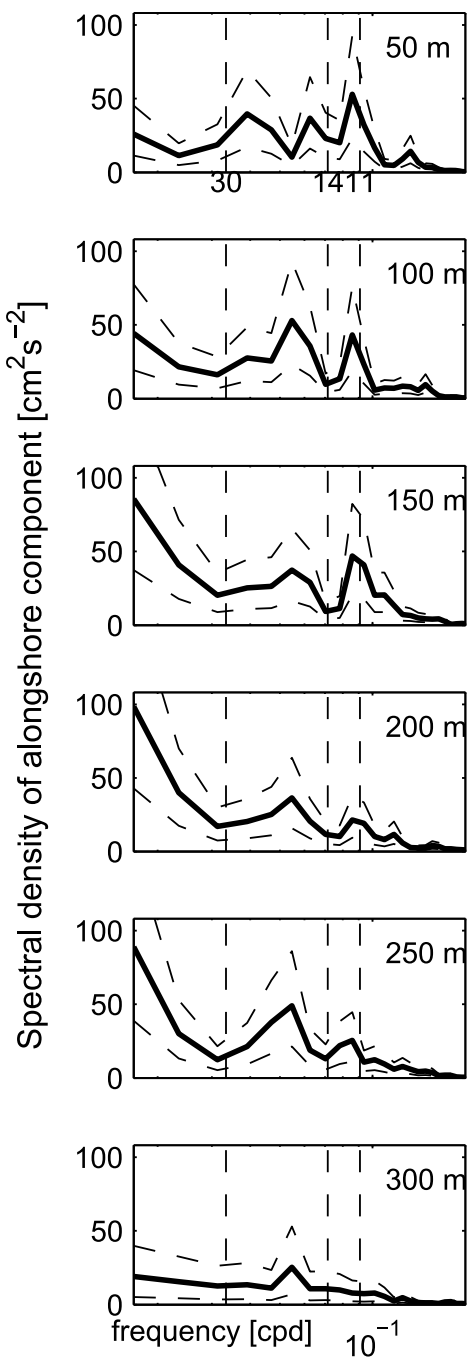

$\mathrm{K} 2$
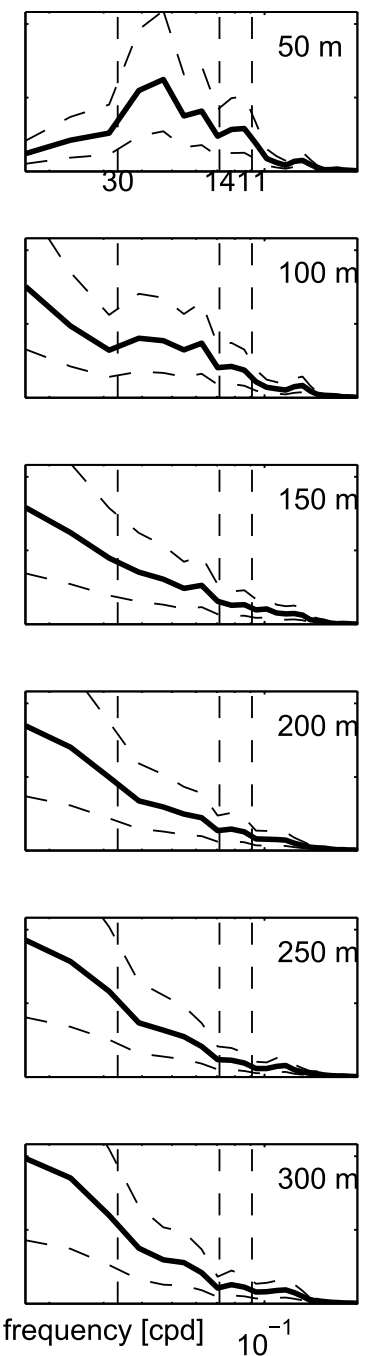

K3
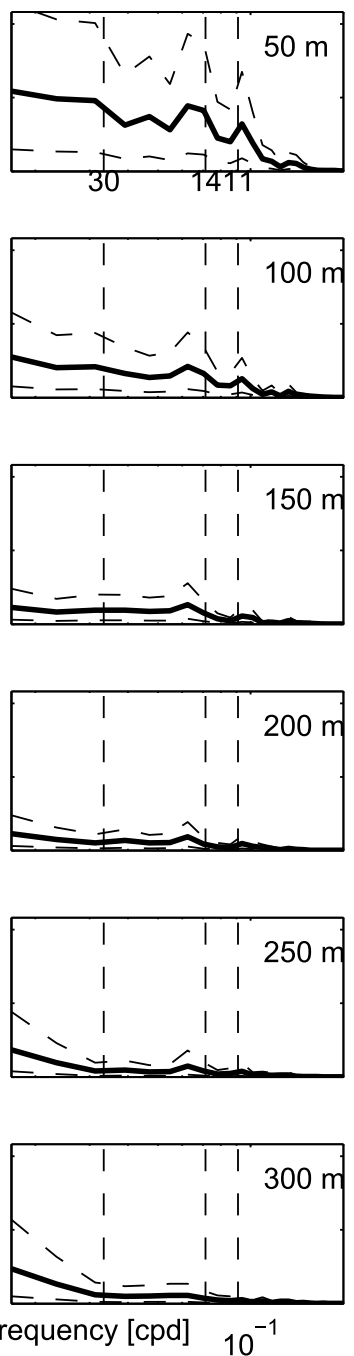

K4
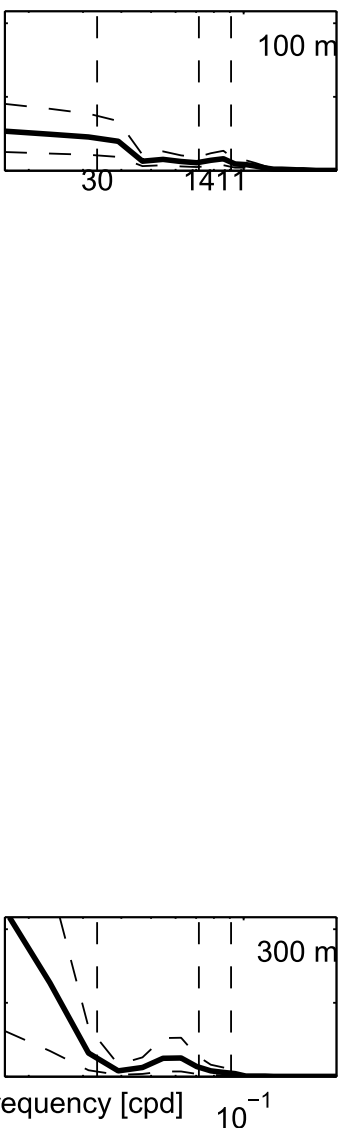

Figure 5. Variance preserving spectra of kinetic energy $\left[\mathrm{cm}^{2} \mathrm{~s}^{-2}\right]$ (solid line) for moorings K1-K4, at 50 to $300 \mathrm{~m}$ depth, from March 2000 to August 2004, with the respective 95\% confidence limits.

the spectral distribution of currents between 50 and $300 \mathrm{~m}$ depth for moorings K1 to K4. High-frequency fluctuations (10-30 days) are more prominent near the coast, at mooring $\mathrm{K} 1$. Farther offshore, at moorings $\mathrm{K} 2$ to K4, these fluctuations have the highest energy in the upper layers and scale down with increasing distance from the NBUC current core. Note that the variance levels at mooring K2 are nearly identical between 150 and $300 \mathrm{~m}$.

\subsection{Cross-Correlation Between Wind Stress and Currents}

[11] We used cross-correlation analysis between the meridional wind stress and alongshore currents to spatially localize the remote forcing across the entire ocean basin. Previous work indicates that the meridional component of wind stress is the prime generator of such coastal-trapped waves [Brink, 1991; Csanady, 1997], and the periods involved correspond to those of the weather systems. The meridional wind stress components are cross-correlated with alongshore currents at $100 \mathrm{~m}$ depth at $11^{\circ} \mathrm{S}$ for moorings
$\mathrm{K} 1-\mathrm{K} 4$ (Figure 6) as this depth level is available for all moorings (see Figure 5).

[12] For mooring K1, two separate intervals are shown, caused by a gap in the available current measurements. Since we are interested in the intraseasonal components of the signal in the 10-30 day band, we applied a 10-30 day band-pass filter to both the atmospheric and oceanic data. The correlation of the meridional wind stress for each grid point with the K1 alongshore current at $100 \mathrm{~m}$ depth is mapped for the entire ocean basin (Figure 6a), and the lag between the two signals is shown in the maps of the right panels. Identical procedures were used for the other moorings, displayed in Figures 6b-6e. Clearly, the lag between the wind stress of a given grid point and the $11^{\circ} \mathrm{S}$ currents decreases with decreasing distance to the moorings, showing a systematic propagation along the shore. For the first interval of available data at mooring K1, the maximum cross-correlation between meridional wind and alongshore current is found between $22^{\circ}$ and $36^{\circ} \mathrm{S}$, which is approximately $1500-2000 \mathrm{~km}$ from the $11^{\circ} \mathrm{S}$ moorings (Figure 6a). The corresponding lag is 6.5 days. For the 2003-2004 period of mooring K1 (Figure 6b), there are 
(a) $10^{\circ}$
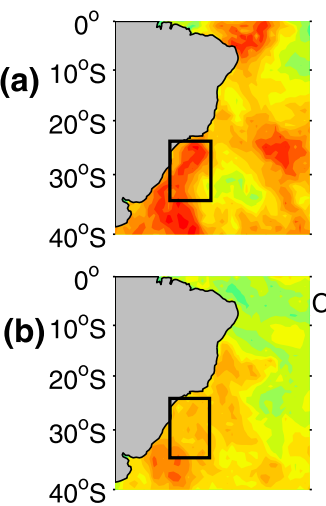

(c)

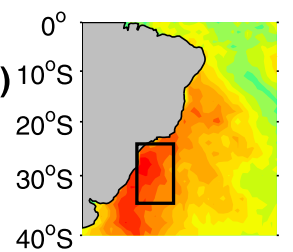

(d)

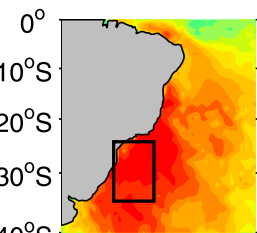

(e)

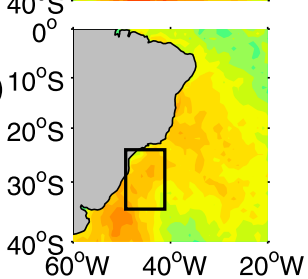

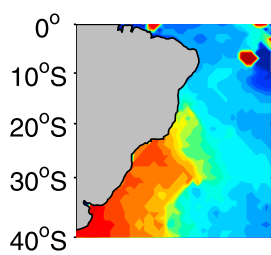
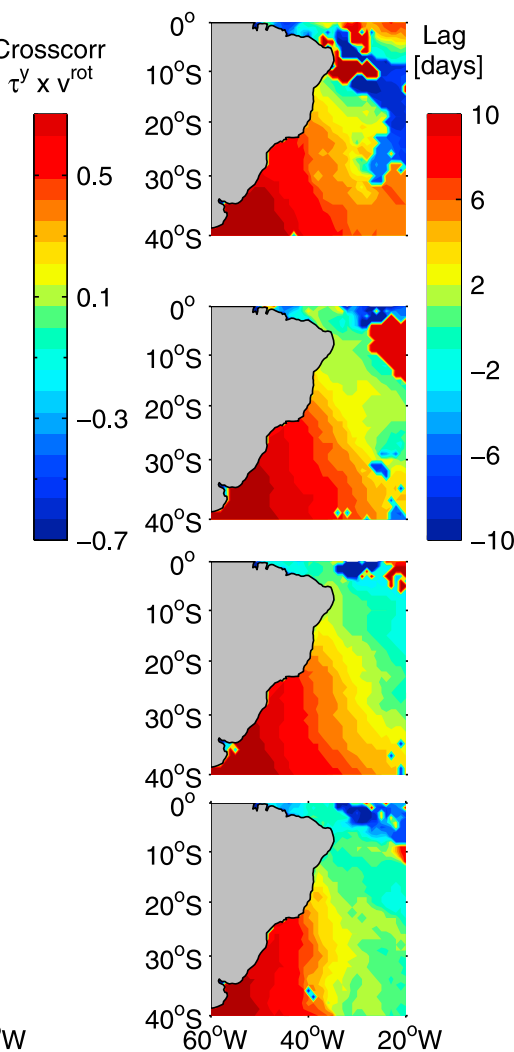

Figure 6. (left) The cross-correlation between meridional wind stress and alongshore currents at $100 \mathrm{~m}$ depth for (a) K1 mooring, 3/2002-1/2003 and (b) 6/2003-8/2004, (c) K2 mooring, 3/2002-5/2004, (d) K3 mooring, 6/20038/2004 and (e) K4 mooring, 3/2002-5/2004. (right) The corresponding lags (currents lagging winds) for the crosscorrelation. Box in cross-correlation maps marks the area of maximum cross-correlation.

weaker cross-correlations, with alongshore currents lagging the wind stress by 10 days. Subsequently, we find a lag of 9 days at mooring K2 (Figure 6c), a lag of 7 days at mooring K3 (Figure 6d), and a lag of 9.5 days for mooring $\mathrm{K} 4$. Here is also where we find the highest cross-correlation

values between meridional wind stress and the alongshore current at about $36^{\circ} \mathrm{S}$ (Figure 6e).

[13] Table 2 summarizes the cross-correlation results of Figure 6 between the meridional wind stress and alongshore current at $11^{\circ} \mathrm{S}$. The coordinates of cross-correlation maxima, the distances to the mooring sites, and the lag period clearly indicate a strong connection between the alongshore current signal at $11^{\circ} \mathrm{S}$ and its remote atmospheric forcing located at about $22^{\circ} \mathrm{S}$ to $36^{\circ} \mathrm{S}$ (box area in Figure 6).

[14] To further investigate this connection, we spatially averaged the meridional wind stress components across the area defined by the highest cross-correlations shown in Figure 6. The resulting time series were cross-correlated with the corresponding time series of meridional currents at $11^{\circ} \mathrm{S}$ (moorings K1-K4) at different depths, 50 to $1000 \mathrm{~m}$ (Figure 7). The highest correlations are found in the nearsurface layers of the NBUC core, gradually weakening downward and outward toward the open ocean. The right panel shows the corresponding lags, where currents lag the wind-forcing by 8 to 10 days (Figure 7, right).

\subsection{Time-Frequency Common Power Between Wind Stress and Currents}

[15] Most traditional mathematical methods to examine periodicities in frequency space, such as the Fourier analysis, implicitly assume that the underlying processes are stationary in time. However, wavelet transforms can be used to analyze a non-stationary time series at many different frequencies and scales by expanding the time series into time-frequency space in order to find localized intermittent periodicities. The wavelet transform is based on a practical guide to wavelet analysis of Torrence and Compo [1998]. One of the problems with the resulting "global wavelet spectra" is a distortion of the energy distribution [Liu et al., 2007; Veleda et al., 2012], with high-frequency peaks shown lower than their low-frequency counterparts. In this work, we construct rectified Cross Wavelet Transform (XWT) by normalizing the wavelet transform by the square root of the scale, based on Veleda et al. [2012].

[16] An XWT analysis was applied to meridional wind stress and alongshore currents at $100 \mathrm{~m}$ depth (moorings $\mathrm{K} 1-\mathrm{K} 4)$. The XWT identifies the regions in time-frequency space with a large common power between two time series. The individual cross-wavelet spectra, from 2002 to 2004, are averaged to form a seasonal ensemble cross-wavelet spectrum, for austral winter (June to November) and austral summer (December to May), respectively. In this case, we used the wind stress data restricted to the region where the highest cross-correlations between the wind stress and alongshore currents were found (see Figure 6).

Table 2. Coordinates of Maximum Cross-Correlation Between Meridional Wind Stress and Alongshore Currents, Corresponding Distances and Lag Periods ${ }^{\mathrm{a}}$

\begin{tabular}{lccr}
\hline Mooring & Maximum Cross-Correlation & Position & Distance (km) \\
\hline K1_I & $0.55(0.076)$ & $25^{\circ} \mathrm{S}-44^{\circ} \mathrm{W}$ & 1550 \\
K1_II & $0.44(0.067)$ & $34^{\circ} \mathrm{S}-47^{\circ} \mathrm{W}$ & 2550 \\
K2 & $0.52(0.049)$ & $28^{\circ} \mathrm{S}-45^{\circ} \mathrm{W}$ & 1890 \\
K3 & $0.64(0.065)$ & $33^{\circ} \mathrm{S}-48^{\circ} \mathrm{W}$ & 8.5 \\
K4 & $0.39(0.046)$ & $36^{\circ} \mathrm{S}-50^{\circ} \mathrm{W}$ & 7 \\
\hline
\end{tabular}

${ }^{\mathrm{a}}$ The $95 \%$ confidence limits are shown in parentheses. 

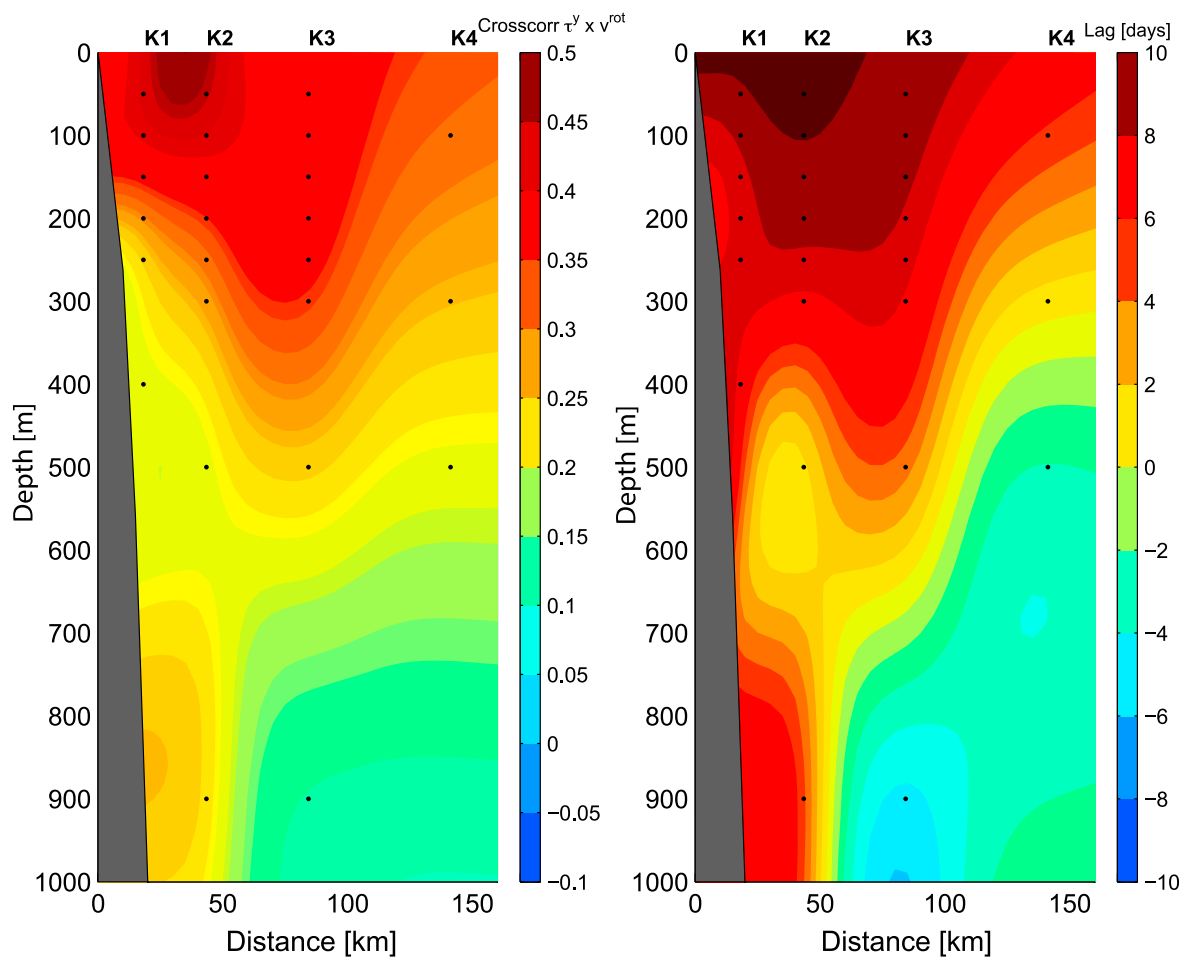

Figure 7. Cross-correlation and lag (in days) between meridional wind stress averaged in the area along the Brazilian coast $\left[22^{\circ} \mathrm{S}-36^{\circ} \mathrm{S}\right]-\left[40^{\circ} \mathrm{W}-50^{\circ} \mathrm{W}\right]$ and alongshore currents at the $11^{\circ} \mathrm{S}$ section.

[17] The seasonal ensemble averages of the XWT between the meridional wind stress averaged over the high crosscorrelation area $\left[22^{\circ}-36^{\circ} \mathrm{S}\right]$ and the corresponding alongshore currents within the matching time interval are shown in Figure 8, with the blocked out "white" margins indicating the "Cone of Influence" (COI), where edge artifacts become important [Grinsted et al., 2004]. The color scale for Figure 8 shows maxima in dark red and minima in dark blue.

[18] Figure 8 clearly indicates that the XWT between currents and wind stress is strongest for the 16-day period during the month of September, linking this periodicity band of the NBUC, at $11^{\circ} \mathrm{S}$ for mooring $\mathrm{K} 1$ (winter) at $100 \mathrm{~m}$ depth, to the wind stress forcing at $22^{\circ}-36^{\circ} \mathrm{S}$ close to the Brazilian coast. The ensemble average XWT for the winter season shows a stronger or more prominent response of the 16-day period of the alongshore currents to the wind stress.

[19] An identical analysis was done for moorings K2, K3 and K4 (Figure 8). The result shows that during austral winter, the 16-day periodicity of the $100 \mathrm{~m}$ currents at moorings $\mathrm{K} 1-\mathrm{K} 4$, along the western and eastern flank of the $\mathrm{NBUC}$ at $11^{\circ} \mathrm{S}$, is linked to the wind-forcing at $22^{\circ}-36^{\circ} \mathrm{S}$ along the coast of Brazil. At mooring K1, the highest energy spans the period from July through October, except for August. For mooring K2, the highest energy is centered in July and weaker in September and November. For moorings $\mathrm{K} 3$ and $\mathrm{K} 4$, the highest energy extents from July through October.

\section{Discussion}

[20] Previous studies in other regions have confirmed the presence of CTWs with typical periods of 5-20 days. Brink [1983] associated these waves with remote wind-forcing, while Battisti and Hickey [1984] determined that the pressure and alongshore velocity fields in the Northwest Pacific may be a response of the wind-forced CTW. The variance in sea surface pressure off Oregon and Washington was found to be generated by wind forcing between San Francisco and Cape Mendocino, California. The signal propagates 900 to $1300 \mathrm{~km}$ northward to Washington-Oregon, arriving there 3 to 4 days later. Brink [1982] also pointed out the agreement between CTW theory and observations off Peru in 1977, indicating free wave phase speeds of about $200 \mathrm{~km} \mathrm{day}^{-1}$, as well as sea level and alongshore velocity fluctuations in the 5-10 day period band. Spillane et al. [1987] found oscillations with intraseasonal periods of 36-73 days close to the coast of Peru, with poleward phase propagation of 150 $200 \mathrm{~km}$ day $^{-1}$. Enfield [1987] established that the intraseasonal sea level variations pointed out by Spillane et al. [1987] are forced in the western equatorial Pacific by atmospheric oscillations, consistent with previous studies with propagation speeds of 216-259 $\mathrm{km} \mathrm{day}^{-1}$.

[21] Smith [1978] found a persistent poleward propagation of fluctuations in currents and sea level along the Peruvian coast between $10^{\circ}$ and $15^{\circ} \mathrm{S}$, with a wave speed of about $200 \mathrm{~km} \mathrm{day}^{-1}$. Enfield and Allen [1980] also estimated the wave phase speed as the ratio of alongshore station separation to the corresponding lag. Along the Peruvian coast, Camayo and Campos [2006] used wavelet analysis to study the intraseasonal current oscillations, suggesting remotely forced baroclinic Kelvin waves with periods between 10 and 20 days, with velocities of approx. $200 \mathrm{~km}^{\text {day }}{ }^{-1}$.

[22] In this work, we establish the propagation of Coastal Trapped Waves along the Brazilian coast as a suitable mechanism for explaining the strong correlation between the meridional wind stress at latitudes of $22^{\circ} \mathrm{S}-36^{\circ} \mathrm{S}$ and the 

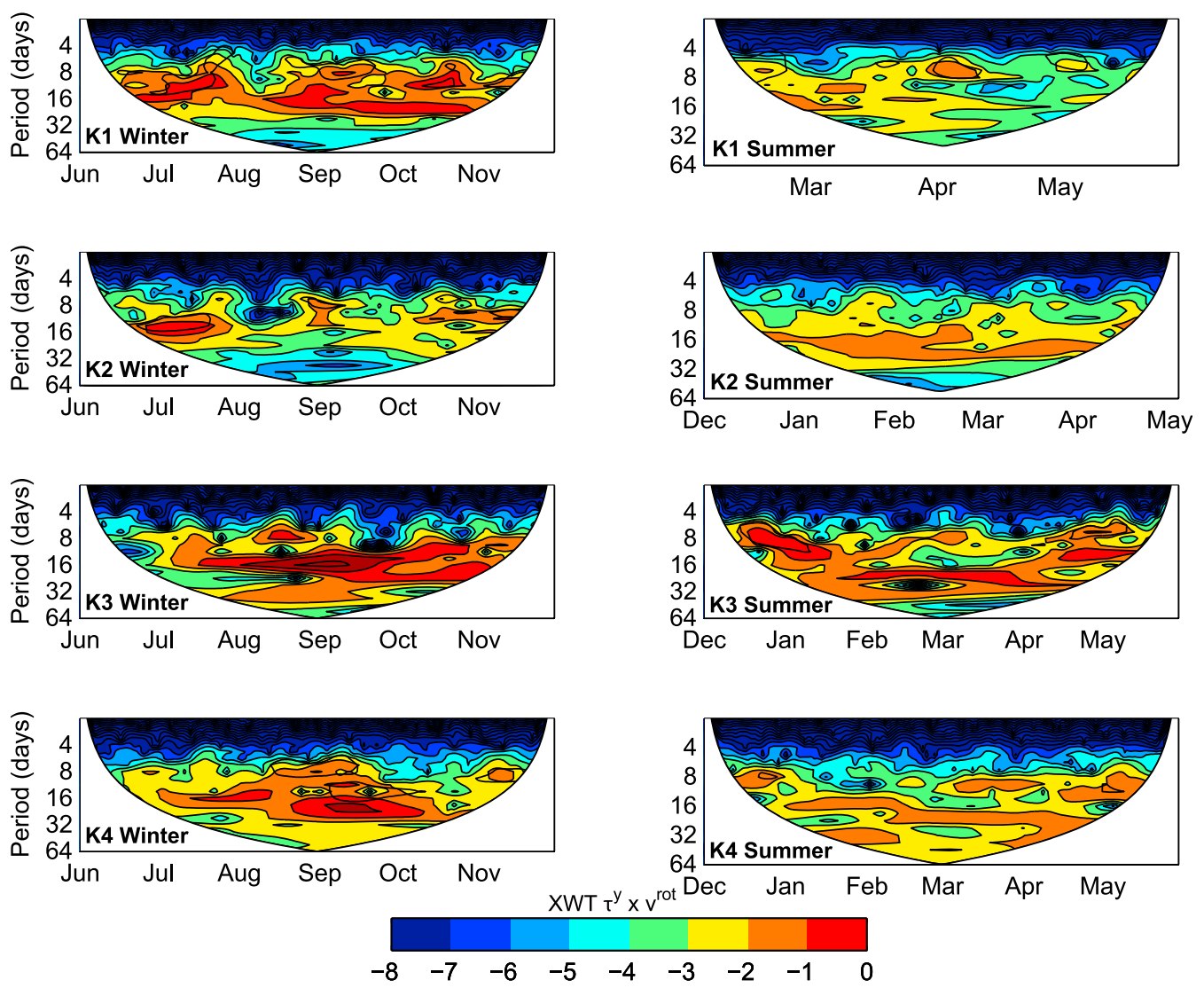

Figure 8. The seasonal ensemble average of the Cross-Wavelet Transform between the meridional wind stress averaged in the area along the Brazilian coast $\left[22^{\circ} \mathrm{S}-36^{\circ} \mathrm{S}\right]-\left[40^{\circ} \mathrm{W}-50^{\circ} \mathrm{W}\right]$ and the respective alongshore current.

alongshore currents at $11^{\circ} \mathrm{S}$. Kelvin waves are low-frequency gravity waves which occur where the deflection caused by the Coriolis force is either constrained by coastlines or goes to zero at the equator. These waves have typical amplitudes of several tens of meters in the thermocline region, and lengths are thousands of kilometers.

[23] Spectral analysis of the current velocities identified high-frequency components present near the surface and gradually decreasing with depth. A fluctuation at 10-30 day periodicity is observed in the four moorings at the jointly available $100 \mathrm{~m}$ depth level. At $11^{\circ} \mathrm{S}$, the thermocline is located at about $65 \mathrm{~m}$ depth [Schott et al., 2005; von Schuckmann, 2006], so that the core of the NBUC is located just below these strong density and temperature gradients, making this flow regime potentially favorable for internal Kelvin wave propagation.

[24] Internal coastal-trapped Kelvin waves may be generated by an abrupt change in the winds and depend on the existence of a coast against which they can lean. Our work showed maximum cross-correlations for the nearshore wind data located between $22^{\circ} \mathrm{S}$ and $36^{\circ} \mathrm{S}$, a region along the Brazilian coast usually referred to in the literature as the Southeast Brazil Bight (SBB) [Castro Filho, 1985; Stech and Lorenzzetti, 1992; Campos et al., 1995; Cirano and Campos, 1996]. The northern boundary of this area corresponds to a relatively narrow shelf close to Cabo Frio $\left(22^{\circ} \mathrm{S}\right)$, where an abrupt change in coastline orientation exists. Furthermore, the SBB is also under the influence of synoptic and mesoscale frontal low pressure systems which interact with the western reaches of the South Atlantic High (or "St. Helena High"). Strong meridional winds from the northeast (NE) occur before the passage of a low pressure system, then rapidly changing to southwesterly winds (SW). These frontal systems have frequencies of 3 to 4 per month [Rodrigues et al., 2004], with average speeds of $500 \mathrm{~km} \mathrm{day}^{-1}$, thereby crossing the SBB region in about 2 days [Stech and Lorenzzetti, 1992]. As a result, these atmospheric anomalies induce drastic changes in wind direction and cause significant disturbances in the ocean, such as mean sea level changes, generation of surface waves and currents [Castro Filho, 1985; Campos et al., 1995]. We argue that the combination of local wind stress variability and the abrupt change in coastline direction reveals the SBB as a preferred locus for CTW generation along the Brazilian shore. The distance between the currents at $11^{\circ} \mathrm{S}$ and the area where high cross-correlations were found is about $1600-2700 \mathrm{~km}$. In addition, the ratio between these distances and their corresponding lag periods yields an equatorward propagation speed of $285 \pm 63 \mathrm{~km} \mathrm{day}^{-1}$ along the Brazilian shore. Coastal trapped waves certainly have major effects on sea level and currents locally, but their far-reaching consequences may not yet be fully explored: As the waves approach the equator, they continue eastward as equatorial Kelvin waves, only to be dispersed again as coastal Kelvin waves along the eastern boundary (off Africa) and also reflected westward as equatorial Rossby waves. The conclusions regarding our 
observations may have significant effects on the entire equatorial waveguide system.

\section{Summary}

[25] The western boundary regime of the tropical South Atlantic is well known for its complex dynamics and multiple scales of variability, with the North Brazil Undercurrent (NBUC) playing an important role in the Atlantic Subtropical Cell (STC) and in the coupled ocean-atmosphere system.

[26] Previous studies of these moorings (K1-K4) at $11^{\circ} \mathrm{S}$ section have shown that the NBUC core, about $50 \mathrm{~km}$ offshore, has a dominant fluctuation with a periodicity of two months [Schott et al., 2005; von Schuckmann, 2006]. In this work we investigate the forcing mechanism behind additional intraseasonal periodicities of the near-surface alongshore current measurements at 2 to 3 weeks. Cross-correlation analysis between currents and meridional wind stress points to the wind field located between $22^{\circ}$ and $36^{\circ} \mathrm{S}$ close to Brazilian coast as the driving mechanism.

[27] The distances between the wind-forcing area and the mooring locations, as well as the corresponding lags, indicate an equatorward propagation speed of $285 \pm 63 \mathrm{~km} \mathrm{day}^{-1}$ along the Brazilian coast. Such distances and travel times suggest Coastal Trapped Waves (CTWs) as the prime candidates for accomplishing this task. Therefore, two of the main ingredients for the existence of CTW are readily available, namely wind stress variability and abrupt change in coastline direction.

[28] We investigated the relationship between the NBUC, wind stress and CTWs by using several statistical and mathematical tools. High-frequency variability is the dominant mode along the western flank of the NBUC. Spectral analysis of the current velocities for K1 (the mooring closest to the coast) shows a spectral peak at 14 and 30 days at $100 \mathrm{~m}$ depth. This peak decreases as we move farther offshore. Crosscorrelation analysis of currents and wind stress along the entire Brazilian coast reveals the precise origin of these fluctuations. In addition, the Cross-Correlation Wavelet Transform accurately identifies the main structures in the frequency-time space where the atmospheric and oceanic time series both had their largest common power.

[29] The correlations between meridional wind stress, from $22^{\circ}$ to $36^{\circ} \mathrm{S}$ near the Brazilian coast, and alongshore currents at $11^{\circ} \mathrm{S}$ are strongest during austral winter and spring. As shown in Enfield and Allen [1980], these signals propagate equatorward with the coast to the left (in the southern hemisphere) and have alongshore speeds consistent with wave propagation processes. Furthermore, the area of origin for the forcing of intraseasonal current signals is dominated by the first baroclinic mode over the continental slope. It has also been shown that this area has stronger density stratification during austral winter than austral summer [Campos et al., 2000], making it more favorable for the propagation of internal Kelvin waves.

[30] Acknowledgments. The authors would like to thank the scientific team of the German Climate Variability and Predictability (CLIVAR) program and, in particular, our colleagues from GEOMAR for providing full access to the K1-K4 mooring data. We also thank the editor and the two anonymous reviewers for their valuable suggestions and comments. The first author thanks Peter Brandt and Lothar Stramma for their assistance during her one-year stay at GEOMAR in Kiel. She also wishes to thank CAPES/DAAD (Coordination for the Improvement of Higher Education
Staff/Deutscher Akademischer Austauschdienst) for scholarship support. R.M. acknowledges financial support from the Pernambuco State Agency FACEPE (APQ-0871-1.05/08). This work was carried out under the National Institute on Science and Technology in Tropical Marine Environments INCT-AmbTropic (CNPq process 565054/2010-4), and under the project BIO-NE (CNPq process 558143/2009-1.

\section{References}

Allen, J. S. (1980), Models of wind-driven currents on the continental shelf, Annu. Rev. Fluid Mech., 12, 389-433, doi:10.1146/annurev. fl.12.010180.002133.

Battisti, D. S., and B. M. Hickey (1984), Application of remote windforced coastal trapped wave theory to the Oregon and Washington coasts, J. Phys. Oceanogr., 14, 887-903, doi:10.1175/1520-0485(1984)014<0887: AORWFC $>2.0 . \mathrm{CO} ; 2$.

Brink, K. H. (1982), A comparison of long coastal trapped wave theory with observations off Peru, J. Phys. Oceanogr., 12, 897-913, doi:10.1175/ 1520-0485(1982)012<0897:ACOLCT $>2.0$. CO;2

Brink, K. H. (1983), The near-surface dynamics of coastal upwelling, Prog. Oceanogr., 12, 223-257, doi:10.1016/0079-6611(83)90009-5.

Brink, K. H. (1991), Coastal-trapped waves and wind-driven currents over the continental shelf, Annu. Rev. Fluid Mech., 23, 389-412, doi:10.1146/ annurev.fl.23.010191.002133.

Camayo, R., and E. J. D. Campos (2006), Application of wavelet transform in the study of coastal trapped waves off the west coast of South America, Geophys. Res. Lett., 33, L22601, doi:10.1029/2006GL026395.

Campos, E. J. D., J. E. Gonçalves, and Y. Ikeda (1995), Water mass characteristics and geostrophic circulation in the South Brazil Bight: Summer of 1991, J. Geophys. Res., 100(C9), 18,537-18,550, doi:10.1029/ 95JC01724.

Campos, E. J. D., D. Velhote, and I. C. A. da Silveira (2000), Shelf break upwelling driven by Brazil current cyclonic meanders, Geophys. Res. Lett., 27, 751-754, doi:10.1029/1999GL010502.

Castelão, R. M., and J. A. Barth (2006), Upwelling around Cabo Frio, Brazil: The importance of wind stress curl, Geophys. Res. Lett., 33, L03602, doi:10.1029/2005GL025182.

Castro Filho, B. M. (1985), Subtidal response to wind forcing in the South Brazil Bight during winter, PhD thesis, 211 pp., Univ. of Miami, Miami, Fla.

Cirano, M., and E. J. D. Campos (1996), Numerical diagnostic of the circulation in the Santos Bight with COROAS hydrographic data, Braz. J. Oceanogr., 44(2), 105-121.

Csanady, G. T. (1997), On the theories that underlie our understanding of continental shelf circulation, J. Oceanogr., 53, 207-229.

Dengler, M., F. A. Schott, C. Eden, P. Brandt, J. Fischer, and R. Zantopp (2004), Break-up of the Atlantic deep western boundary current into eddies at $8^{\circ} \mathrm{S}$, Nature, 432, 1018-1020, doi:10.1038/nature03134

Enfield, D. B. (1987), The intraseasonal oscillation in eastern Pacific sea levels: How is it forced?, J. Phys. Oceanogr., 17, 1860-1876, doi:10.1175/1520-0485(1987)017<1860:TIOIEP $>2.0$. CO;2.

Enfield, D. B., and J. S. Allen (1980), On the structure and dynamics of monthly mean sea level anomalies along the Pacific coast of North and South America, J. Phys. Oceanogr., 10, 557-578, doi:10.1175/15200485(1980)010<0557:OTSADO > 2.0.CO;2.

Gordon, A. L. (1986), Interocean exchange of thermocline water, J. Geophys. Res., 91, 5037-5046, doi:10.1029/JC091iC04p05037.

Grinsted, A., J. C. Moore, and S. Jevrejeva (2004), Application of the crosswavelet transform and wavelet coherence to geophysical time series, Nonlinear Processes Geophys., 11, 561-566, doi:10.5194/npg-11-5612004.

Harrison, D. E. (1989), On climatological monthly mean wind stress and wind stress curl fields over the world ocean, J. Clim., 2, 57-70, doi:10.1175/1520-0442(1989)002<0057:OCMMWS>2.0.CO;2.

Liu, Y., X. S. Liang, and R. H. Weisberg (2007), Rectification of the bias in the wavelet power spectrum, J. Atmos. Oceanic Technol., 24(12), 20932102, doi:10.1175/2007JTECHO511.1.

Mayer, D. A., and R. H. Weisberg (1993), A description of COADS surface meteorological fields and the implied Sverdrup transports for the Atlantic Ocean from $30^{\circ} \mathrm{S}$ to $60^{\circ} \mathrm{N}, \mathrm{J}$. Phys. Oceanogr., 23, 2201-2221, doi:10.1175/1520-0485(1993)023<2201:ADOCSM>2.0.CO;2.

Molinari, R. L. (1983), Observations of near-surface currents and temperature in the central and western tropical Atlantic Ocean, J. Geophys. Res., $88,4433-4438$.

Rhein, M., L. Stramma, and U. Send (1995), The Atlantic Deep Western Boundary Current: Water masses and transports near the equator, J. Geophys. Res., 100, 2441-2451, doi:10.1029/94JC02355.

Rodrigues, M. L. G., D. Franco, and S. Sugahara (2004), Climatologia de frentes frias no litoral de Santa Catarina, Braz. J. Geophys., 22(2), 135-151. 
Rodrigues, R. R., L. M. Rothstein, and M. Wimbush (2007), Seasonal variability of the South Equatorial Current bifurcation in the Atlantic Ocean: A numerical study, J. Phys. Oceanogr., 37, 16-30, doi:10.1175/ JPO2983.1.

Schmitz, W. J., Jr. (1995), On the interbasin-scale thermohaline circulation, Rev. Geophys., 33, 151-173, doi:10.1029/95RG00879.

Schott, F., and C. W. Böning (1991), The WOCE model in the western equatorial Atlantic: Upper-layer circulation, J. Geophys. Res., 96, 6993-7004, doi:10.1029/90JC02683.

Schott, F., J. Fischer, J. Reppin, and U. Send (1993), On mean and seasonal currents and transports at the western boundary of the equatorial Atlantic, J. Geophys. Res., 98, 14,353-14,368, doi:10.1029/93JC01287.

Schott, F., P. Brandt, M. Hamann, J. Fisher, and L. Stramma (2002), On the boundary flow off Brazil at $5-10^{\circ} \mathrm{S}$ and its connection to the interior tropical Atlantic, Geophys. Res. Lett., 29(17), 1840, doi:10.1029/ 2002 GL014786.

Schott, F. A., J. P. McCreary, and G. C. Johnson (2004), Shallow overturning circulation of the tropical-subtropical oceans, in Earth's Climate: The Ocean Atmosphere Interaction, Geophys. Monogr. Ser., vol. 147, edited by C. Wang, S.-P. Xie, and J. A. Carton, pp. 261-304, AGU, Washington, D. C., doi:10.1029/147GM15

Schott, F., M. Dengler, R. Zantopp, L. Stramma, J. Fischer, and P. Brandt (2005), The shallow and deep western boundary circulation of the South Atlantic at $5^{\circ}-11^{\circ} \mathrm{S}, \mathrm{J}$. Am. Meteorol. Soc., 35, 2031-2053.

Silva, M. A., M. Araújo, J. Servain, P. Penven, and C. Lentini (2009), Highresolution regional ocean dynamics simulation in the southwestern tropical Atlantic, Ocean Modell., 30, 1-29, doi:10.1016/j.ocemod.2009.07.002.

Smith, R. L. (1978), Poleward propagating perturbations in currents and sea levels along the Peru coast, J. Geophys. Res., 83, 6083-6092, doi:10.1029/JC083iC12p06083.

Spillane, M. C., D. B. Enfield, and J. S. Allen (1987), Intraseasonal oscillations in sea level along the west coast of the Americas, J. Am. Meteorol. Soc., 17, 313-325.
Stech, J. L., and J. A. Lorenzzetti (1992), The response of the South Brazil Bight to the passage of wintertime cold fronts, J. Geophys. Res., 97(C6), 9507-9520, doi:10.1029/92JC00486.

Stramma, L. (1991), Geostrophic transport of the South Equatorial Current in the Atlantic, J. Mar. Res., 49, 281-294, doi:10.1357/ 002224091784995864.

Stramma, L., and F. Schott (1999), The mean flow field of the tropical Atlantic Ocean, Deep Sea Res., Part II, 46, 279-303, doi:10.1016/ S0967-0645(98)00109-X.

Stramma, L., J. Fischer, and J. Reppin (1995), The North Brazil Undercurrent, Deep Sea Res., Part I, 42(5), 773-795, doi:10.1016/0967-0637(95) 00014-W.

Stramma, L., J. Fischer, P. Brandt, and F. Schott (2003), Circulation, variability and near-equatorial meridional flow in the central tropical Atlantic, in Interhemispheric Water Exchanges in the Atlantic Ocean, edited by G. J. Goni and P. Malanotte-Rizzoli, pp. 1-22, Elsevier, Amsterdam.

Stramma, L., M. Rhein, P. Brandt, M. Dengler, C. Böning, and M. Walter (2005), Upper ocean circulation in the western tropical Atlantic in boreal fall 2000, Deep Sea Res., Part I, 52, 221-240, doi:10.1016/j.dsr.2004. 07.021 .

Torrence, C., and G. P. Compo (1998), A practical guide to wavelet analysis, Bull. Am. Meteorol. Soc., 79(1), 61-78, doi:10.1175/1520-0477 (1998)079<0061:APGTWA>2.0.CO;2.

Trenberth, K. E., W. G. Large, and J. G. Olson (1990), The mean annual cycle in global ocean wind stress, J. Phys. Oceanogr., 20, 1742-1760, doi:10.1175/1520-0485(1990)020<1742:TMACIG >2.0.CO;2.

Veleda, D., R., Montagne, and M. Araújo (2012), Cross-wavelet bias corrected by normalizing scales, J. Atmos. Oceanic Technol., 29, 1401-1408, doi:10.1175/JTECH-D-11-00140.1.

von Schuckmann, K. (2006), Intraseasonal variability in the southwestern and central tropical Atlantic Ocean, $\mathrm{PhD}$ thesis, 140 pp., Christian Albrechts Univ. Kiel, Kiel, Germany.

Zhang, H.-M., J. J. Bates, and R. W. Reynolds (2006), Assessment of composite global sampling: Sea surface wind speed, Geophys. Res. Lett., 33, L17714, doi:10.1029/2006GL027086. 